University of Nebraska - Lincoln

DigitalCommons@University of Nebraska - Lincoln

Biological Systems Engineering: Papers and Publications

2-1989

\title{
Evaluation of Irrigation Planning Decisions
}

Derrel L. Martin

University of Nebraska-Lincoln, derrel.martin@unl.edu

James R. Gilley

University of Nebraska-Lincoln

Raymond J. Supalla

University of Nebraska-Lincoln, rsupalla1@unl.edu

Follow this and additional works at: https://digitalcommons.unl.edu/biosysengfacpub

Part of the Biological Engineering Commons

Martin, Derrel L.; Gilley, James R.; and Supalla, Raymond J., "Evaluation of Irrigation Planning Decisions" (1989). Biological Systems Engineering: Papers and Publications. 55.

https://digitalcommons.unl.edu/biosysengfacpub/55

This Article is brought to you for free and open access by the Biological Systems Engineering at DigitalCommons@University of Nebraska - Lincoln. It has been accepted for inclusion in Biological Systems Engineering: Papers and Publications by an authorized administrator of DigitalCommons@University of Nebraska Lincoln. 


\title{
Evaluation of Irrigation Planning Decisions
}

\author{
Derrel L. Martin, ${ }^{1}$ James R. Gilley, ${ }^{2}$ and Raymond J. Supalla ${ }^{3}$ \\ ${ }^{1}$ Assistant Professor, Agricultural Engineering Department, University of Nebraska-Lincoln \\ ${ }^{2}$ Professor, Agricultural Engineering Department, University of Nebraska-Lincoln \\ ${ }^{3}$ Professor, Agricultural Economics Department, University of Nebraska-Lincoln
}

\begin{abstract}
A method is developed to determine optimal irrigation strategies for a single season using crop production functions which incorporate physically based coefficients. The relationship of yield to evapotranspiration is used to develop the yield-irrigation function. The physical parameters used in the production function can be determined from field measurements or various types of computer simulation. Using this approach, the optimal irrigated area and depth of water to apply can be related to prices, costs, and physical parameters. This produces a more general solution than commonly used production functions that depend on limited experimental results. The optimal irrigation depth and irrigated area can be determined for either land or water limiting conditions. The analysis also allows consideration of different irrigated and dryland crops. Three examples are analyzed to illustrate the use of the technique and to develop some general guidelines.
\end{abstract}

\section{Introduction}

Economic evaluation of irrigation alternatives relies upon crop production functions relating yield to gross irrigation to define the return from irrigation. Production functions are usually developed from field experiments conducted under specific climatic and soil conditions and often with a limited amount of data. Yet, both soil and climatic variability can be substantial. The characteristics of different types of irrigation systems cause variations in the amount of water required to produce a given yield. Also, production functions as traditionally developed are difficult to apply to locations or years that are different than the original data. The production function and analysis presented here is more general than traditional functions and can be applied to a wider range of conditions to provide more universal management guidelines.

A contradiction exists in the literature regarding the optimal irrigated area and application depth when the volume of available irrigation water is limited. Stewart and Hagan (1973) argued that the limited water supply should be spread uniformly over the irrigable area if dryland production is profitable, or applied at a depth just greater than the breakeven depth when dryland production is unprofitable. Barrett and Skogerboe (1980) showed that, for water limiting conditions, the optimal depth to apply was nearly constant regardless of the application efficiency of the irrigation system. They concluded that the optimal irrigation depth for any application efficiency was near that required to produce the maximum yield with a very efficient system. This would not suggest that the limited water supply should be spread across the irrigable area as Stewart and Hagan recommended. A major difference between the two analyses was the shape of the yield function. The yield function used by Stewart and Hagan increased continu- 
ously from the dryland to the maximum yield. The functions used by Barrett and Skogerboe required some irrigation before any yield was produced.

A generalized framework is needed to develop irrigation plans. In addition, previous research needs to be incorporated into a universal analysis that embodies deficit irrigation management options. Barrett and Skogerboe (1980) expanded the net return function used by Stewart and Hagan (1973) to include more management factors, but they did not consider dryland production using a different crop than the one irrigated. A generalized approach to irrigation management and planning is developed here. Example applications are included to illustrate use of the procedure. Finally, the effect of efficiency on the optimal depth for limited water supplies is discussed. The effect of the uniformity of application has not been included into the analysis at this time.

\section{Theory}

\section{Net Return Function}

The net return from irrigation depends upon the income produced from the irrigated and dryland areas, the cost of irrigation water, costs of production per unit of irrigated and dryland areas, and any annual start-up costs associated with irrigation:

$$
N_{r}=\left[V_{i} Y(I)-C_{i} I-C_{1}\right] A_{i}+\left[V_{d} D_{y}-C_{d}\right]\left[A_{t}-A_{i}\right]-C_{s}
$$

in which $N_{r}=$ total net return from irrigation; $V_{i}=$ net value of the irrigated crop, defined as crop price less yield dependent costs; $Y(I)=$ yield from irrigated cropland as a function of irrigation; $V_{d}=$ net value of the dryland crop, defined as crop price less yield dependent costs; $D_{y}=$ yield from dryland area; $A_{i}=$ area irrigated; $A_{t}=$ total irrigable area; $C_{i}=$ constant cost of irrigation water; $I=$ irrigation depth; $C_{1}=$ annual production cost for irrigation, exclusive of land and irrigation cost, on a per-unit land area basis; $C_{d}=$ annual production cost per unit land area for the dryland crop; and $C_{s}=$ annual start-up cost of irrigation.

This net return function is similar to that given by Yaron and Bresler (1983) and Barrett and Skogerboe (1980), except in this analysis the dryland crop can be different than the irrigated crop. The net return function represents three terms: the return from the irrigated crop, the return from the dryland crop, and the annual start-up cost of irrigation. The annual start-up cost is the money spent prior to the irrigation season that is due to the decision to irrigate that year. An example is the connection charge for using electricity to pump water. This charge must be paid before any water is pumped. However, it may be possible to avoid this cost if the irrigator decides not to irrigate that season. The start-up cost does not include fixed costs such as depreciation, taxes, or interest which must be paid whether the land is irrigated or not.

The return per unit area is the value of the product minus the production costs and the cost of irrigation water. The value of the crop can be adjusted down from the selling price to account for costs that are related to crop yield. Examples are the nitrogen fertilizer costs or the cost of harvesting, drying, and storing the product. It is assumed that the cost per unit volume of irrigation water is constant. The irrigation related production costs represent those incurred because a given unit of land is to be irrigated. These include the annual costs of planting, 
fertilizing, and raising an irrigated crop but are exclusive of the cost of the irrigation water. Other examples of irrigation related production costs are the labor involved in setting up the irrigation system, for example, ditching, or smoothing a surface irrigation field. Those costs would not be necessary if the unit of land were not irrigated.

\section{Physically Based Coefficients for Crop Production Functions}

Crop production functions are necessary to evaluate irrigation management decisions. Martin et al. (1984) developed a method to estimate the necessary coefficients for commonly used production functions. The technique is based upon a linear relationship of yield to evapotranspiration (ET):

$$
Y=Y_{d}+b\left(E T-E T_{d}\right) \text { for } E T_{d} \leq E T \leq E T_{m}
$$

in which $Y=$ crop yield; $Y_{d}=$ dryland yield for the irrigated crop; $b=$ empirical constant; $E T$ = seasonal evapotranspiration; $E T_{m}=$ seasonal evapotranspiration when the crop never suffers water stress; and $E T_{d}=$ seasonal evapotranspiration for dryland.

The method assumes that a yield-irrigation production function can be expressed as:

$$
Y=Y_{d}+\left(Y_{m}-Y_{d}\right) R\left(I_{r}\right) \quad \text { for } 0 \leq I_{r} \leq 1
$$

in which $Y_{m}=$ maximum yield of the irrigated crop; $R\left(I_{r}\right)=$ yield response ratio for irrigation; $I_{r}=$ relative irrigation depth; $I_{r}=I / I_{m}$, with $I=$ depth of irrigation; and $I_{m}=$ depth of irrigation required to produce the maximum yield.

The yield response ratio is the percentage of the yield increase between the maximum and dryland yield that is produced with a given relative depth of irrigation. Two conditions apply to the yield response ratio function:

1. $R(0)=0$, since the yield should equal the dryland yield when no irrigation is applied.

2. $R(1)=1$, because the yield must equal the maximum yield when the maximum irrigation depth is applied.

A third condition was assumed similar to that shown by Stewart and Hagan (1973): namely, that the first unit of irrigation applied will be used completely for ET.

Many production functions used over this range of irrigation have three coefficients. Generally, these coefficients are determined from regression analysis of data from a specific experiment. Using the three conditions previously listed, Martin et al. (1984) developed relationships between physical parameters and these coefficients for a quadratic, exponential, and power function used to describe the yield response ratio. Martin et al. showed that using the physically based coefficients in the production functions represented experimental data as well as regression analysis results for data from Nebraska. The quadratic function developed using the technique is essentially the same as that found by Stewart and Hagan (1973) through regression.

The power function form of the generalized equation is used here to analyze management for adequate and inadequate water supplies and is given by: 


$$
Y=Y_{d}+\left(Y_{m}-Y_{d}\right)\left[1-\left(1-I_{r}\right)^{1 / \beta}\right]
$$

in which $\beta=\left(E T_{m}-E T_{d}\right) / I_{m}$. The definition of $\beta$ emerges from the analysis of Martin et al. (1984).

The parameter $\beta$ represents the portion of the irrigation that is used by the crop as evapotranspiration when producing the maximum yield. The value of $\beta$ is highly dependent on the application efficiency of the irrigation system. However, the effects of irrigation scheduling, soil characteristics, and other irrigation management factors are included in $\beta$. When the value of $\beta$ is high (near 1 ), all aspects of irrigation management must be performed efficiently. If $\beta$ is low, one or more factors may contribute to inefficient water use. In general, $\beta$ values near 1 represent efficient irrigation and low $\beta$ values indicate inefficient irrigation.

The physically based coefficients require estimates of the maximum $E T\left(E T_{m}\right)$, the dryland $E T\left(E T_{d}\right)$, the maximum irrigation requirement $\left(I_{m}\right)$, the maximum yield $\left(Y_{m}\right)$, and the slope of the yield versus ET function $(b)$. The first four of these parameters can be estimated from experimental data or through simulation. The value of the $b$ parameter is available for specific crops and regions in many cases (Doorenbos and Kassam 1979). The advantage of using physically based coefficients in the yield function is that the coefficients can be estimated from several sources and do not depend upon regression of specific experimental data. This allows for the analysis of technological and environmental changes that cannot be considered with traditional production functions.

\section{Land Limiting Conditions}

When land is the limiting resource, i.e., ample water is available, the primary planning decision is the optimal depth of water to apply. Depending upon breakeven conditions, either none of the area should be irrigated, or the entire area should be irrigated at the optimum depth.

The decision concerning whether or not to irrigate can be evaluated using the net return equation (Equation 1). Assuming uniform net returns per unit area, the entire area should be watered if the estimated net return from irrigating at the optimum level exceeds the dryland net return. This condition can be expressed as:

$$
\left[V_{i} Y(I)-C_{i} I-C_{1}\right] A_{t}-C_{s} \geq\left(V_{d} D_{y}-C_{d}\right) A_{t}
$$

This expression shows that the decision to irrigate depends upon the net return to irrigation per unit area $\left(V_{i} Y(I)-C_{i} I-C_{1}\right)$, the return to dryland per unit area $\left(V_{d} D_{y}-C_{d}\right)$, and the irrigation start-up costs $\left(C_{s}\right)$. As irrigation start-up costs increase, the breakeven area required to justify irrigation increases, given a constant difference between net returns for irrigation and dryland per unit area.

The optimal irrigation depth will be that at which the return from irrigation per unit land area is largest. Taking the derivative of the net return function with respect to the irrigation depth and setting the result equal to zero gives the necessary relationship:

or

$$
\frac{\partial N_{r}}{\partial I}\left|=A_{i} V_{i} \frac{\partial Y}{\partial I}\right|_{I^{*}}-A_{i} C_{i}=0
$$




$$
\left.\frac{\partial Y}{\partial I}\right|_{I^{*}}=\frac{C_{i}}{V_{i}}
$$

in which $I^{*}$ is the optimal irrigation depth when water supplies are adequate.

Once the optimal depth is known, the breakeven condition should be analyzed. The increase of net return above that for dryland $\left(N_{i}\right)$ due to irrigating the entire area with the optimal depth $\left(I^{*}\right)$ is given by:

$$
N_{1}=\left[V_{i} Y\left(I^{*}\right)-C_{i} I^{*}-C_{1}-V_{d} D_{y}+C_{d}\right] A_{t}-C_{s}
$$

If the value of $N_{1}$ is greater than zero, the entire area should be irrigated with the optimal depth. If $N_{1} \leq 0$, dryland production would be preferable as long as it is profitable (i.e., if $\left[V_{d} D_{y}-C_{d}\right]>0$ ). Also, an alternate irrigated crop could be considered at this point.

The production function using physically based coefficients can be combined with the optimality and breakeven criteria. The resulting expression for the optimal irrigation depth for adequate water supplies $\left(I^{*}\right)$ is

$$
I^{*}=I_{m}\left[1-\alpha^{\beta /(1-\beta)}\right]
$$

in which $\alpha=C_{i} / b V_{i}$.

The breakeven irrigation depth for adequate water supplies cannot be derived explicitly but can be expressed as:

$$
\left(1-I_{r}\right)^{1 / \beta}+\alpha I_{r} / \beta=\gamma
$$

in which $I_{r}=$ relative irrigation depth $\left(I / I_{m}\right)$; and $\gamma=\left[\left(V_{i} Y_{m}-C_{1}\right)-\left(V_{d} D_{y}-C_{d}\right)-\right.$ $\left.C_{s} / A_{t}\right] /\left[V_{i}\left(Y_{m}-Y_{d}\right)\right]$. The solution generally has two roots which define a feasible range for irrigation.

The solutions for the optimal depth and breakeven equations are illustrated in Figure 1 for an example where $\beta=0.5$ and $\gamma=0.9$. As the cost of water increases, $\alpha$ increases, and the feasible range of irrigation depths narrows until water costs exceed the marginal returns from irrigating. The maximum feasible value of $\alpha\left(\alpha_{\max }\right)$, as shown in Figure 1, was determined by combining Equations 8 and 9, which gives:

$$
\alpha_{\max }-[1-\beta] \alpha_{\max }^{1 /(1-\beta)}=\beta \gamma
$$

Three parameters emerge from the analysis for adequate water supplies:

1. $\beta=\left(E T_{m}-E T_{d}\right) / I_{m}$.

2. $\alpha=C_{i} / b V_{i}$, the ratio of the irrigation water cost to the income produced per unit of $E T$.

3. $Y=\left[V_{i} Y_{m}-V_{d} D_{y}-\left(C_{1}-C_{d}\right)-C_{s} / A_{t}\right] / V_{i}\left(Y_{m}-Y_{d}\right)$.

These factors are sufficient to evaluate the economics of irrigating with adequate water supplies. The generalized results for $\alpha_{\max }$ and $I^{*}$ are shown in Figure 2 for several values of $\beta$. The procedure for using these curves is as follows.

1. Calculate the value of $\gamma$.

2. Calculate the value of $\beta$.

3 . Determine $\alpha_{\max }$ using the top of Figure 2. 


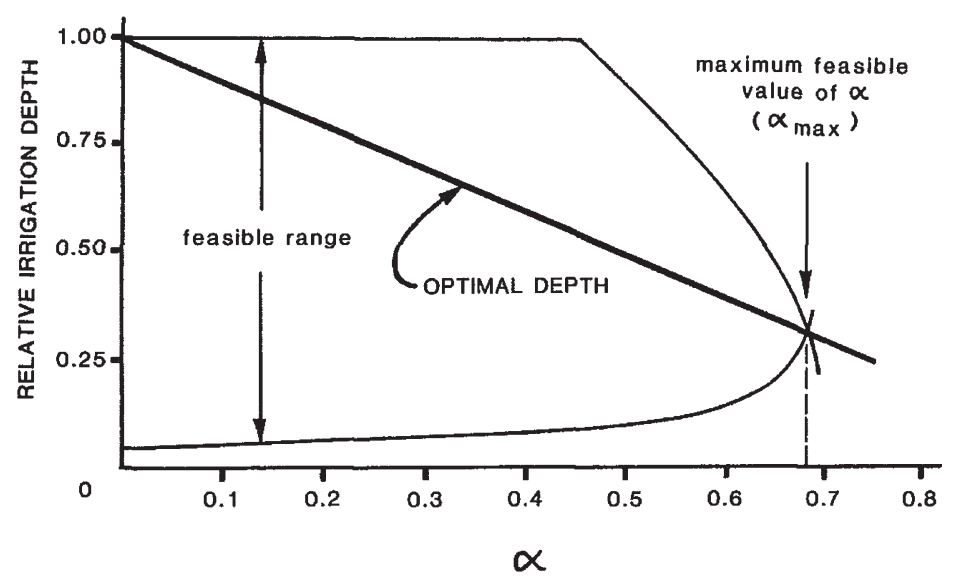

Figure 1. Example of feasible range and optimal irrigation depth when water supplies are adequate; values of $\beta=0.5$ and $\gamma=0.9$ were used for example (see text for definition of variables).

4. Calculate the actual value of $\alpha$.

5. If $\alpha_{\max } \geq \alpha_{\max }$, irrigation is infeasible and dryland production or other crops should be considered.

6. If $\alpha<\alpha_{\max }$, the optimal relative irrigation depth $I^{*}$ should be determined from the bottom of Figure 2.

7. Finally, determine the optimal irrigation depth using the maximum irrigation requirement, i.e., $I^{*}=I_{r}{ }^{*} I_{m}$.

The optimal relative irrigation depth increases as $\beta$ increases. For efficient irrigation $(\beta=0.9)$, the optimal depth is greater than $80 \%$ of the maximum requirement for most of the feasible range. Inefficient irrigation (low $\beta$ values) produces less return per unit of water and therefore has a smaller optimal relative depth.

The optimal irrigation depth decreases as $\alpha$ increases. The value of $\alpha$ increases when either the water cost rises or the value of a unit of ET drops. Although water cost per unit is constant, the marginal return from irrigation increases as the depth applied decreases. Thus, the depth where irrigation will be most profitable is smaller when $\alpha$ is high. The value of $\gamma$ is independent of the depth of water applied and only affects the range of feasibility.

\section{Water Limiting Conditions}

When the water supply is inadequate to irrigate the entire area with the net return maximizing depth, either the irrigated area or the depth applied, or both, must be decreased. An example of the trade-off between the irrigated area and the depth is illustrated in Figure 3 for a water supply of 800 ha-cm $(80,000$ $\mathrm{m}^{3}$ ). In the example, the optimal land limiting irrigation depth is $40 \mathrm{~cm}$, which allows up to 20 ha to be irrigated. The net return per unit area is constant for an irrigated area up to 20 ha. Thus, for an irrigated area of 20 ha or less, the problem is really a land limiting condition. However, when the irrigated area 

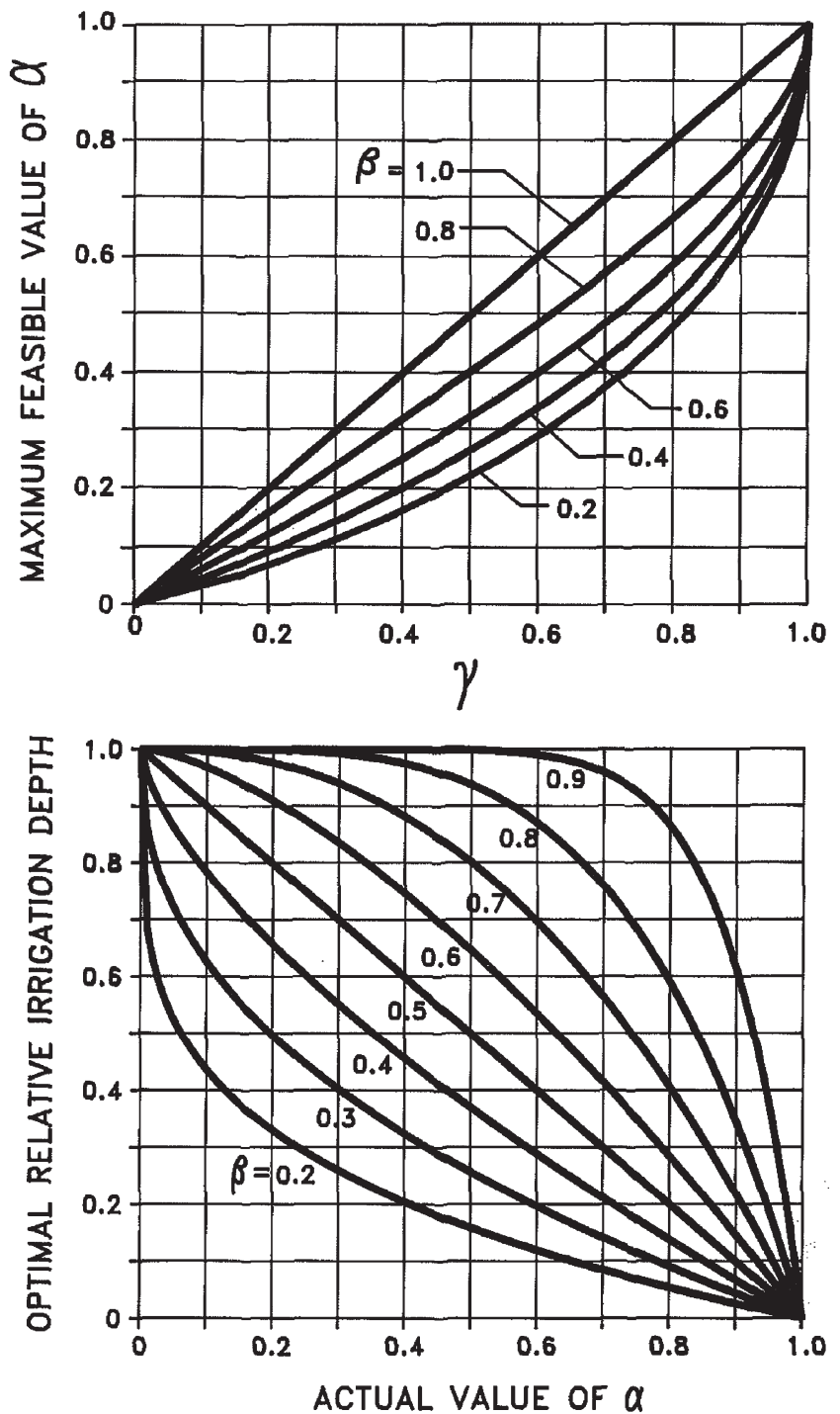

Figure 2. Breakeven and optimal relative irrigation depth for land limiting conditions (parameters are defined in text).

is increased above 20 ha, the net return continues to increase. Since more than 20 ha are irrigated, the depth applied must be less than $40 \mathrm{~cm}$. When the irrigated depth decreases, the yield also declines, resulting in less return per unit of land. However, the net return per unit area is still positive. Thus, the irrigated area should be increased until the marginal net return per unit area is zero. This occurs at about 40 ha in Figure 3. With inadequate water supplies, 


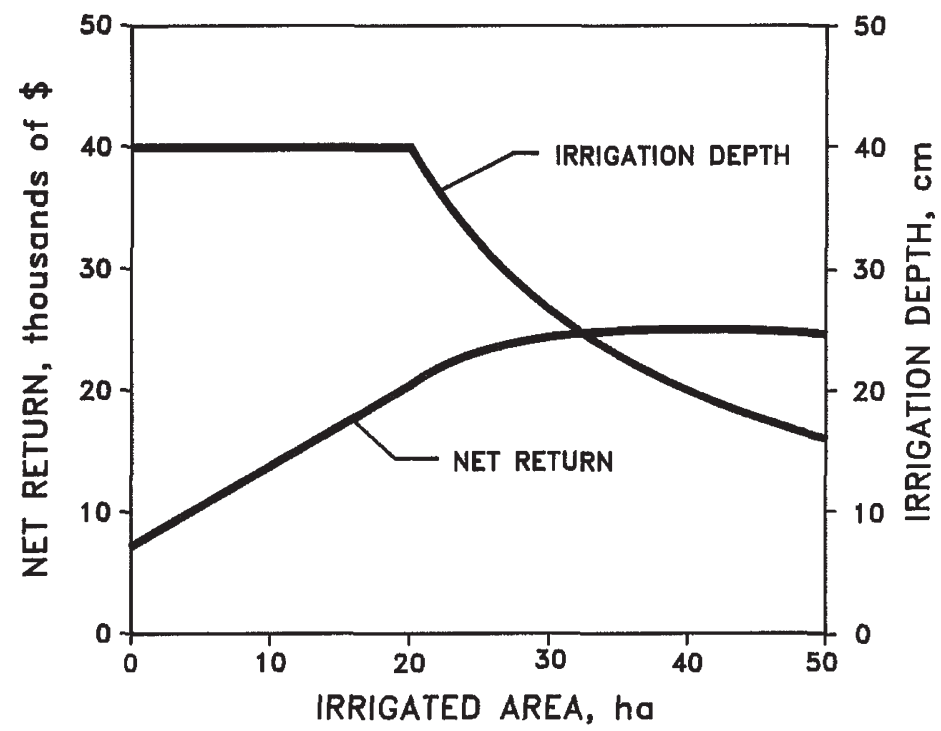

Figure 3. Example of net return and irrigation depth when 800 ha-cm allocation of water is inadequate for maximum net return on 50 ha.

there may be a relatively wide plateau over which the net return is nearly constant for changes in the area irrigated. Three evaluations are required for managing inadequate water supplies. First, the land limiting analysis is required to determine if the water supply is limiting. The second decision involves determining the optimal irrigated area and associated depth. Third, the net return for the optimal conditions must be compared to that from dryland. The first step follows directly from the preceding section. The second and third steps in this evaluation will be developed in this section.

When the water supply is limited, the irrigated area and the depth of irrigation are related by:

$$
A_{i}=W_{s} / I
$$

in which $W_{s}=$ the supply of water available.

This equation implies uniform application across the area irrigated. The net return function for inadequate water supplies can be expressed by

$$
N_{r}=\left[V_{i} Y(I)-C_{i} I-C_{1}-V_{d} D_{y}+C_{d}\right]\left(W_{s} / I\right)-C_{s}+\left[V_{d} D_{y}-C_{d}\right] A_{t}
$$

The optimal depth of irrigation is determined by setting the marginal net return from irrigation to zero and solving for the optimal depth:

$$
V_{i}\left[Y(I)-\left.I \frac{\partial Y}{\partial I}\right|_{I^{0}}\right]=C_{1}+V_{d} D_{y}-C_{d}
$$

in which $I^{0}=$ the optimal water limiting irrigation depth. 
Once the optimal depth has been determined, the optimal irrigated area can be calculated using Equation 11. These values can be used to determine if the net return from the optimal conditions exceeds that for dryland. The net return above dryland for the optimal condition is given by:

$$
N_{d}=\left[V_{i} Y\left(I^{0}\right)-C_{i} I^{0}-C_{1}-V_{d} D_{y}+C_{d}\right]\left(W_{s} / I^{0}\right)-C_{s}
$$

Thus, if $N_{d}>0$, irrigation with the limited supply is feasible.

When irrigation is infeasible, the optimal conditions do not specify dryland production. This occurs because of the discontinuity of the net return function between dryland and zero irrigation due to the annual start-up cost. The discontinuity requires the two-step process of finding the optimum and then checking for feasibility.

The optimal conditions for an inadequate water supply can be combined with the crop production function to develop generalized management criteria. When the optimal water limiting depth is combined with the production function, the following relationship emerges:

$$
\left(1-I_{r}^{O}\right)^{1 / \beta}+\left(I_{r}^{\mathrm{O}} / \beta\right)\left(1-I_{r}^{\mathrm{O}}\right)^{(1-\beta) / \beta}=f
$$

in which $I_{r}^{\mathrm{O}}=$ optimal relative irrigation depth for water limiting conditions; and $f=\left[\left\{V_{i} Y_{m}{ }^{r}-C_{1}\right)-\left(V_{d} D_{y}-C_{d}\right)\right] / V_{i}\left(Y_{m}-Y_{d}\right)$.

The breakeven relative irrigation depth can be determined from solution of the following equation for an inadequate water supply:

$$
\left(1-I_{r}\right)^{1 / \beta}+a I_{r} / \beta=f
$$

in which

$$
a=\left(C_{i} W_{s}+C_{s}\right) / b V_{i} W_{s}
$$

The optimal and breakeven conditions can be combined to determine the minimum feasible value of the $f$ parameter $\left(f_{\min }\right)$ :

$$
f_{\min }=a / \beta
$$

General solutions are presented in Figure 4 for $f_{\min }$ and the optimal relative irrigation depth.

Three parameters emerge from the analysis of the optimal conditions for an inadequate water supply. The first parameter $(\beta)$ is the same as for adequate water supplies. The second parameter $(f)$ is the net return per unit area above dryland when all water costs are ignored, relative to the maximum potential income per unit area from irrigating. Since the irrigated area may vary when water supplies are inadequate, the $f$ parameter is directly included in the determination of the optimal irrigation depth. The minimum breakeven value of $f$ increases as the water and start-up costs increase. The third parameter $(a)$ is the ratio of the cost of the water plus start-up cost to the potential income from the water when used 

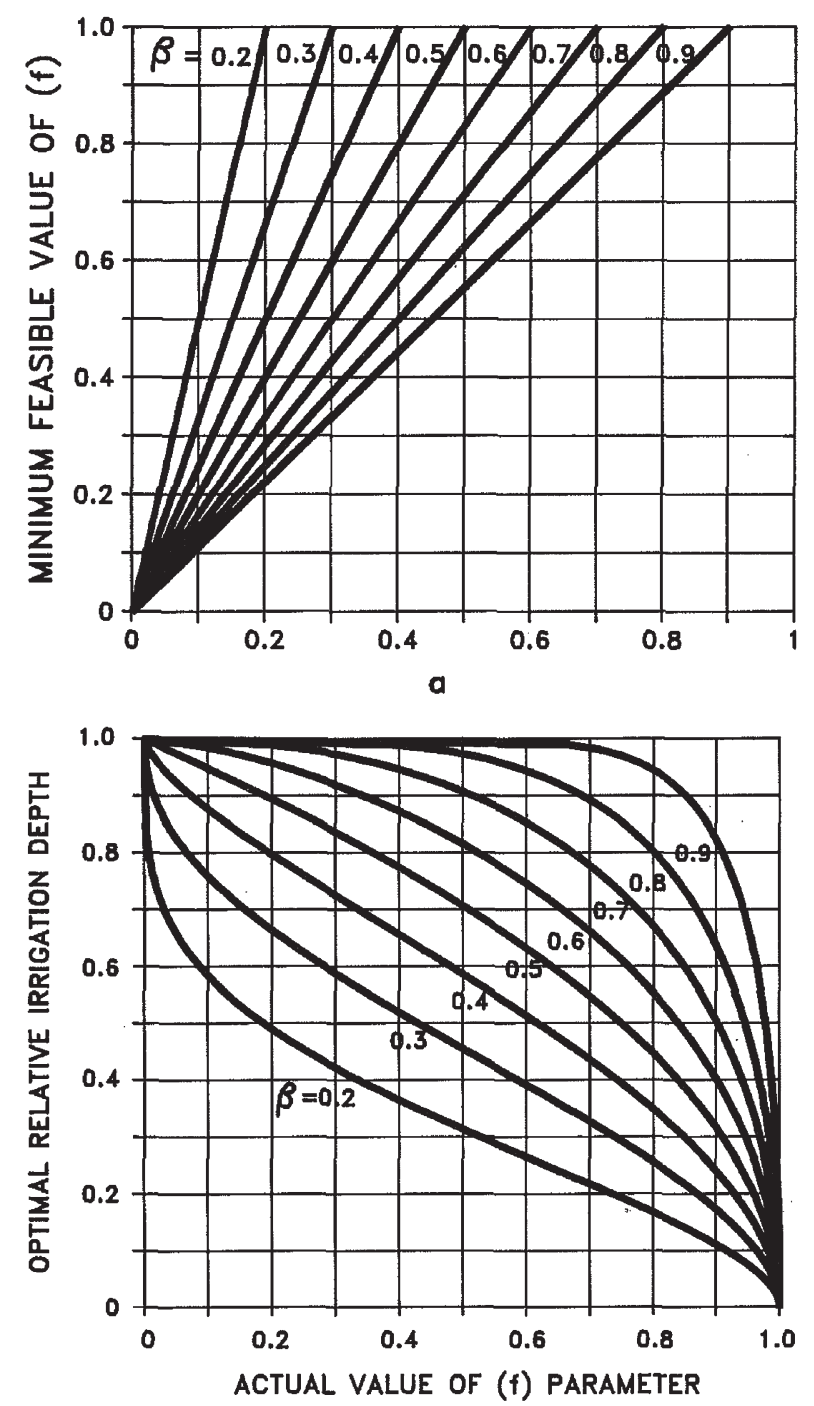

Figure 4. Breakeven and optimal relative irrigation depth for water limiting conditions (parameters are defined in text).

completely for ET. The water supply volume is fixed for inadequate water supplies, so the water and startup costs are also fixed. The fixed cost must be paid regardless of how the water is distributed over the irrigable area. Thus, $(a)$ is used to determine feasibility and does not directly enter into determining the optimal depth.

The optimal depth increases as the efficiency of irrigation increases (i.e., high $\beta$ values). This occurs for two reasons. First, for a given amount of water, efficient irrigation can adequately supply a larger area without stress than is possible with 
inefficient systems. Second, the production function becomes nearly linear for efficient irrigation (high $\beta$ values). Thus, the last increment of water applied with efficient irrigation produces about as much net return as the first unit of water applied. By irrigating near to the maximum yield requirement, the irrigated area will be reduced, resulting in smaller production costs while still generating about the same amount of net return per unit of water.

\section{Applications}

Application of the methodology was illustrated using three sources of data. The procedure from Doorenbos and Kassam (1979) was used to estimate values for the coefficients of the production function for a region where field experimental data are unavailable. The second application used results from water stress experiments with corn for different locations, and the third used a simulation program to generate the parameters for the production function.

\section{Use of Doorenbos and Kassam Method}

The method of Doorenbos and Kassam (1979) was used to estimate maximum crop yield $\left(Y_{m}\right)$, maximum $E T$ requirement $\left(E T_{m}\right), E T$ for dryland conditions $\left(E T_{d}\right)$, and the dryland yield $\left(Y_{d}\right)$ for corn and grain sorghum. The results of those calculations for a silt loam soil in central Nebraska are summarized in Table 1.

The value of the yield coefficient (b) was estimated using a value of 2.0 for Doorenbos and Kassam's yield response factor $\left(k_{y}\right)$. This value of $k_{y}$ represents stress that occurs during the flowering and yield formation growth stages. Water stress generally occurs at that time in central Nebraska where the largest portion of the annual rainfall occurs during the spring and where silt loam soils hold approximately $16.7 \mathrm{~cm}$ of available water per meter of soil. The yield coefficient (b) is related to the yield response factor by:

$$
b=k_{y} Y_{m} / E T_{m}
$$

The computed value of $b$ was $332 \mathrm{~kg} /$ ha-cm.

The net irrigation requirement $\left(I_{n}\right)$ was determined using a soil water balance:

$$
I_{n}=E T_{m}-P_{e}-W_{b}
$$

Table 1. Yield and ET values for silt loam soil in central Nebraska ${ }^{a}$

\begin{tabular}{lcc}
\hline $\begin{array}{c}\text { Physical parameter } \\
(1)\end{array}$ & $\begin{array}{c}\text { Corn } \\
(2)\end{array}$ & $\begin{array}{c}\text { Sorghum } \\
(3)\end{array}$ \\
\hline Evapotranspiration $(\mathrm{cm})$ & & \\
Maximum $\left(E T_{m}\right)$ & 63.6 & 55.6 \\
Dryland $\left(E T_{d}\right)$ & 43.2 & 41.9 \\
Grain yield $(\mathrm{kg} / \mathrm{ha})$ & & \\
Maximum $\left(Y_{m}\right)$ & 10,560 & 6,540 \\
Dryland $\left(Y_{d}\right)$ & 3,840 & 5,030 \\
\hline
\end{tabular}

a Estimated using Doorenbos and Kassam's (1979) procedure. 
Table 2. Results of experiments on water stress of corn

\begin{tabular}{|c|c|c|c|c|c|c|c|c|c|}
\hline Site & $\begin{array}{l}\text { Location - Year } \\
\text { (2) }\end{array}$ & $\begin{array}{c}Y_{m} \\
\text { (kg/ha) } \\
\text { (3) }\end{array}$ & $\begin{array}{c}Y_{d} \\
(\mathrm{~kg} / \mathrm{ha}) \\
(4)\end{array}$ & $\begin{array}{c}E T_{m} \\
(\mathrm{~cm}) \\
(5)\end{array}$ & $\begin{array}{l}E T_{d} \\
(\mathrm{~cm}) \\
(6)\end{array}$ & $\begin{array}{c}\begin{array}{c}I_{m} \\
(\mathrm{~cm})\end{array} \\
(7)\end{array}$ & $\begin{array}{l}b(\mathrm{~kg} / \\
\text { ha-cm) } \\
(8)\end{array}$ & (9) & $\begin{array}{l}\text { Source } \\
(10)\end{array}$ \\
\hline 1 & Davis -1972 & 10,060 & 3,835 & 62.0 & 37.6 & 45.2 & 255 & 0.54 & Stewart et al. (1975) \\
\hline 2 & Davis -1974 & 11,570 & 6,665 & 67.3 & 43.7 & 40.9 & 208 & 0.58 & Stewart et al. (1977) \\
\hline 3 & Ft. Collins - 1974 & 9,680 & 4,340 & 44.5 & 32.3 & 18.3 & 438 & 0.67 & Stewart et al. (1977) \\
\hline 4 & Grand Junction -1972 & 8,110 & 4,090 & 64.0 & 33.0 & 50.0 & 129 & 0.62 & Skogerboe et al. (1979) \\
\hline 5 & Logan-1975 & 7,860 & 2,640 & 54.9 & 22.4 & 34.8 & 161 & 0.93 & Stewart et al. (1977) \\
\hline 6 & North Platte-1978 & 10,500 & 2,075 & 59.2 & 30.0 & 37.1 & 290 & 0.79 & Maurer (1981) \\
\hline
\end{tabular}

1 ha- $\mathrm{cm}=100 \mathrm{~m}^{3}$

in which $P_{e}=$ effective rainfall; and $W_{b}=$ allowable soil water depletion during the season.

The effective monthly precipitation was estimated using the Soil Conservation Service (SCS) method (Doorenbos and Pruitt 1977). The cumulative effective precipitation for the period from May through September averages approximately 30.5 $\mathrm{cm}$. The allowable soil moisture depletion was assumed to equal $50 \%$ of the available water in a $1.2 \mathrm{~m}$ root zone. Using these data and an irrigation application efficiency of $85 \%$, the maximum gross irrigation requirement was computed as $30.5 \mathrm{~cm}$.

This example illustrates one method that can be used to develop reasonable estimates of the physical parameters for the crop production function without using data specifically relating yield to irrigation depth. If the cost terms and crop values were also estimated, optimal seasonal planning decisions could be developed from this point.

\section{Results from Selected Corn Experiments}

Results from water stress experiments with corn, summarized in Table 2, were used to illustrate how the method could be applied for various locations. The production per unit of ET $(b)$ varies between locations and years and would vary for other factors such as variety, length of growing season, cultural practices, fertility, etc. An example of the variation in $\beta$ for basically the same irrigation system is shown for sites 1 and 2 . There is a variation in $\beta$ of 0.04 which would be due to management and climatic factors. The $\beta$ value also varies between sites because of differences in irrigation systems and management.

The optimal strategy for a total irrigable area $\left(A_{t}\right)$ of 53 ha was evaluated for each site as a function of the value of corn and the cost of water. Corn was selected for the dryland crop. The start-up cost was assumed to be $\$ 1,800$. The irrigated and dryland corn production costs were estimated as $284 \$$ / ha and 138 $\$ /$ ha, respectively.

Sites with low $\beta$ values (i.e., less efficient irrigation) have small optimal relative irrigation depths when land is the limiting resource (Table 3). The optimal depth increases as the crop value increases and as the water cost decreases. The smallest depth that was feasible was $77 \%$ of the maximum irrigation requirement. In some cases, as with sites 4 and 5, there is a small margin between the optimal and the breakeven net return. At other sites (i.e., 3 and 6) the breakeven point is well below the water and crop values analyzed, and the optimal irrigation depth is always near the yield maximizing depth. In general, the optimal irrigation 
Table 3. Optimal relative irrigation depths for land limiting conditions for water stress experiments

\begin{tabular}{|c|c|c|c|c|c|c|c|c|c|}
\hline \multirow[b]{2}{*}{$\begin{array}{l}\text { Site } \\
(1)\end{array}$} & \multicolumn{3}{|c|}{$C_{i}=2 \$ /$ ha-cma } & \multicolumn{3}{|c|}{$C_{i}=5 \$ /$ ha $-\mathrm{cm}$} & \multicolumn{3}{|c|}{$C_{i}=10 \$ /$ ha-cm } \\
\hline & $\begin{array}{c}V_{i}= \\
0.079 \\
\$ / \mathrm{kg}^{\mathrm{b}} \\
(2)\end{array}$ & $\begin{array}{c}V_{i}= \\
0.14 \\
\$ / \mathrm{kg} \\
(3)\end{array}$ & $\begin{array}{c}V_{i}= \\
0.20 \\
\$ / \mathrm{kg} \\
(4)\end{array}$ & $\begin{array}{c}V_{i}= \\
0.079 \\
\$ / \mathrm{kg} \\
(5)\end{array}$ & $\begin{array}{c}V_{i}= \\
0.14 \\
\$ / \mathrm{kg} \\
(6)\end{array}$ & $\begin{array}{c}V_{i}= \\
0.20 \\
\$ / \mathrm{kg} \\
(7)\end{array}$ & $\begin{array}{l}V_{i}= \\
0.079 \\
\$ / \mathrm{kg} \\
(8)\end{array}$ & $\begin{array}{c}V_{i}= \\
0.14 \\
\$ / \mathrm{kg} \\
(9)\end{array}$ & $\begin{array}{l}V_{i}= \\
0.20 \\
\$ / \mathrm{kg} \\
(10)\end{array}$ \\
\hline $\begin{array}{c}1^{c} \\
\beta=0.54\end{array}$ & 0.93 & 0.96 & 0.98 & 0.81 & 0.90 & 0.93 & * & 0.78 & 0.86 \\
\hline $\begin{array}{c}2 \\
\beta=0.58\end{array}$ & 0.95 & 0.97 & 0.98 & 0.81 & 0.91 & 0.95 & * & 0.77 & 0.86 \\
\hline $\begin{array}{c}3 \\
\beta=0.67\end{array}$ & 1.00 & 1.00 & 1.00 & 0.98 & 0.99 & 1.00 & 0.92 & 0.98 & 0.99 \\
\hline $\begin{array}{c}4 \\
\beta=0.62\end{array}$ & 0.93 & 0.97 & 0.98 & 0.88 & 0.93 & 0.79 & * & * & 0.79 \\
\hline $\begin{array}{c}5 \\
\beta=0.93\end{array}$ & 1.00 & 1.00 & 1.00 & 1.00 & 1.00 & 1.00 & * & 1.00 & 1.00 \\
\hline $\begin{array}{c}6 \\
\beta=0.79\end{array}$ & 1.00 & 1.00 & 1.00 & 1.00 & 1.00 & 1.00 & 0.96 & 1.00 & 1.00 \\
\hline $\begin{array}{l}{ }^{\mathrm{a}} C_{i}=\mathrm{co} \\
\mathrm{b}^{\mathrm{b}} V_{i}=\mathrm{va} \\
{ }^{\mathrm{c}} \beta=\text { wa }\end{array}$ & of irri & & . & & & & & 1 ha-cm & $100 \mathrm{~m}^{3}$ \\
\hline
\end{tabular}

depth is near the yield maximizing depth when land is the limiting resource.

When water is limiting, locations with low $\beta$ values (sites 1 and 2) have smaller optimal relative irrigation depths than more efficient irrigation such as sites 5 and 6 (Figure 5). As the value of the crop increases, the optimal depth decreases, meaning that a larger area could be irrigated. Obviously, the area irrigated must be less than or equal to the total irrigable area.

The water and start-up costs, and the water allocation, enter the breakeven analysis for water limiting conditions. Using Equations 16 and 17, the amount of water needed to break even can be calculated as a function of the crop value and the irrigation water cost (Table 4). For water allocations less than those shown in Table 4, it would be better to shift to a different crop or to not irrigate. When the value of the crop is high, production using smaller allocations is feasible. The breakeven allocation increases as the cost of water increases. When irrigation is efficient and when crops respond favorably to increases in ET (i.e., high values for $b$ ), profitable irrigation can be maintained on smaller water allocation. For less efficient irrigation or crops that do not respond as favorably to irrigation, larger water allocations are required to break even. Note that the results in Table 4 only indicate where irrigation becomes feasible, they do not indicate the optimal irrigated area or depth. These results also illustrate that continuing to irrigate with a limited water supply is feasible even for small allocations in many regions.

\section{Analysis of Multiple Seasons}

A simulation program (Martin et al., 1984) was used to calculate the parameters for the crop production function. The model was used to simulate the evapo- 


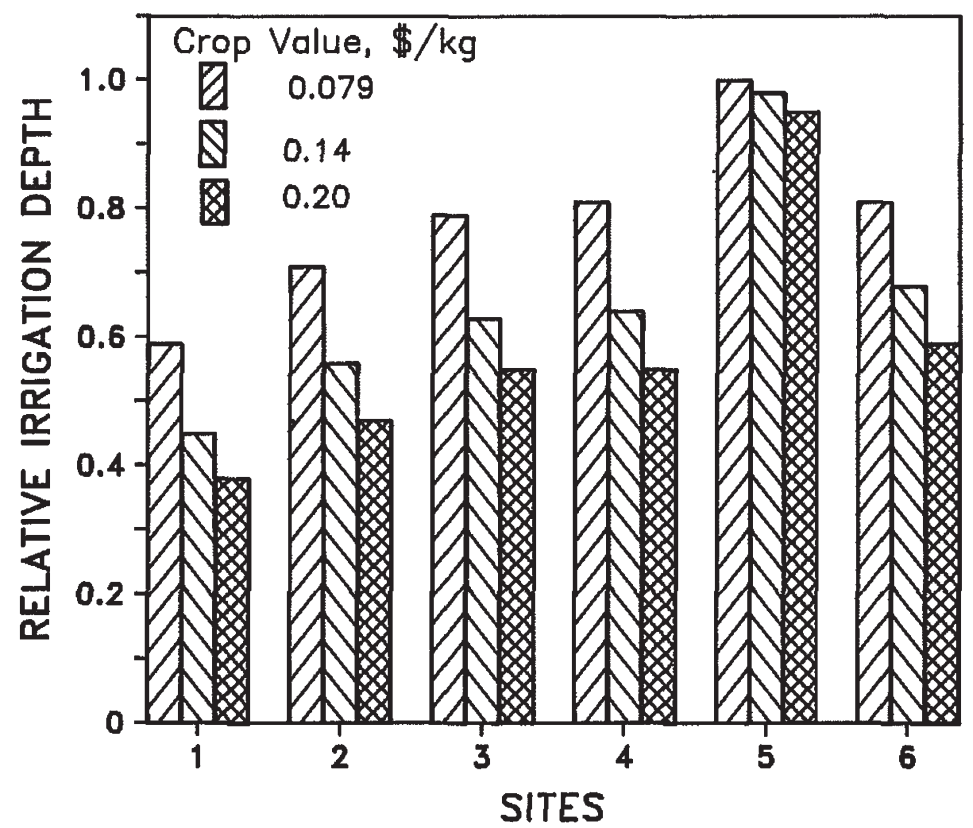

Figure 5. Optimal relative irrigation depth for water limiting conditions for water stress experiments.

Table 4. Breakeven water allocation for differing crop values and irrigation water cost for water limiting case

\begin{tabular}{|c|c|c|c|c|c|c|}
\hline \multirow{2}{*}{$\begin{array}{c}\text { Crop } \\
\text { value } \\
(\$ / \mathrm{kg}) \\
(1)\end{array}$} & \multicolumn{6}{|c|}{ Breakeven Water Allocations, ha-cm } \\
\hline & $\begin{array}{l}\text { Site } 1 \\
\text { (2) }\end{array}$ & $\begin{array}{c}\text { Site } 2 \\
(3)\end{array}$ & $\begin{array}{c}\text { Site } 3 \\
(4)\end{array}$ & $\begin{array}{c}\text { Site } 4 \\
\quad(5)\end{array}$ & $\begin{array}{c}\text { Site } 5 \\
(6)\end{array}$ & $\begin{array}{c}\text { Site } 6 \\
(7)\end{array}$ \\
\hline
\end{tabular}

(a) Irrigation Water Cost, $2 \$ /$ ha-cm

\begin{tabular}{|c|c|c|c|c|c|c|}
\hline 0.079 & 310 & 443 & 133 & 1,220 & 311 & 145 \\
\hline 0.140 & 127 & 158 & 58 & 285 & 121 & 68 \\
\hline 0.200 & 80 & 96 & 37 & 161 & 75 & 45 \\
\hline
\end{tabular}

\begin{tabular}{|c|c|c|c|c|c|c|}
\hline \multicolumn{7}{|c|}{ (b) Irrigation Water Cost, $5 \$ /$ ha-cm } \\
\hline 0.079 & 641 & 1,700 & 172 & $\#^{a}$ & 644 & 191 \\
\hline 0.140 & 161 & 215 & 64 & 543 & 152 & 77 \\
\hline 0.200 & 92 & 115 & 39 & 221 & 86 & 48 \\
\hline \multicolumn{7}{|c|}{ (c) Irrigation Water Cost, $10 \$ /$ ha-cm } \\
\hline 0.079 & \# & \# & 328 & \# & \# & 408 \\
\hline 0.140 & 293 & 535 & 77 & \# & 262 & 98 \\
\hline 0.200 & 124 & 169 & 44 & 572 & 113 & 56 \\
\hline
\end{tabular}

a \# = infeasible solutions that are less than breakeven.

1 ha-cm $=100 \mathrm{~m}^{3}$ 
transpiration for dryland corn and grain sorghum, and for corn irrigated to produce the maximum yield. The amount of irrigation required for maximum yield was also predicted for center-pivot irrigation on a sandy loam soil. An available water holding capacity of $12.5 \mathrm{~cm}$ of water per meter of soil depth was assumed for the sandy loam soil. The $k_{y}$ values for corn and grain sorghum were assumed to be 1.50 and 1.11 , respectively.

The production function was used to determine the optimal strategy for center-pivot irrigation for 27 years of climatic data for southwest Nebraska. The optimal irrigation depth for irrigated corn when the water supply did not limit irrigation was evaluated. The optimal irrigated depth and area of irrigated corn and area of dryland grain sorghum with a limited water supply of 1,030 ha-cm $\left(103,000 \mathrm{~m}^{3}\right)$ were also evaluated.

The amount of irrigation water required to produce the maximum yield of corn is quite variable in this region (Table 5). The gross water requirement ranged from 19 to $61 \mathrm{~cm}$ with a mean of $41.9 \mathrm{~cm}$. The smallest $\beta$ value occurred in 1958 where about half of the maximum irrigation was converted to $E T$, while the highest value was in 1968 at $88 \%$. Irrigation water was used more efficiently in dry years that had large irrigation requirements than in years with more rainfall.

The optimal land limiting depth was determined for each season when irrigation water cost 2 or $5 \$ /$ ha-cm. The data used to optimize are summarized in Table 6. Results from the land limiting solution show that the optimal depth of irrigation is essentially the yield maximizing depth for both water costs (Table 5). The optimal depth was less than $90 \%$ of the yield maximizing depth for only one season (1958) for water costing $5 \$ /$ ha-cm $\left(0.05 \$ / \mathrm{m}^{3}\right)$. The optimal irrigation depth when the available water supply is 1030 ha-cm $\left(103,000 \mathrm{~m}^{3}\right)$ varies considerably between years. In five of the 27 years the optimal policy was to spread the available water supply over the irrigable area resulting in an optimal depth of $19.6 \mathrm{~cm}$, and in three years it was optimal to reduce the irrigated area and to apply more than $90 \%$ of the yield maximizing depth. In 1962, the allocation of 1030 ha-cm did not produce a water limiting condition since the optimal land limiting depth is less than the water limiting depth. The mean optimal irrigated area for the 27 years was about 34 ha, with a range from 19 to 52.6 ha and a distribution that was skewed toward areas smaller than the average (Figure 6). The variability is due to the profitability of dryland corn relative to dryland sorghum and the maximum irrigation requirement. When irrigation requirements are low, the yield for dryland corn is large enough to be more profitable than sorghum, and the entire area should be planted to irrigated corn. In some years the yield of corn on sandy loam soil when the whole area is irrigated is so low that startup costs are barely covered. In those cases, the depth should be increased and the irrigated area decreased, resulting in more dryland sorghum.

In planning for an irrigation season, the optimal strategy for the upcoming season is unknown in locations with variable climates. The results listed in Table 5 are an analysis of what would have been optimal with prior knowledge of growing season weather. The results in Figure 3 indicated that a net return plateau may exist for water limiting conditions where about the same net return is produced for a wide range of irrigated areas. If this conclusion is valid for multiple seasons as well, it may be possible to irrigate a constant area every year and not suffer large losses. To evaluate this hypothesis, the net return from a constant 
Table 5. Simulation and optimization results from southwest nebraska for sandy loam soil and center pivot irrigation; water limiting solutions are for water supply of 1030 ha-cm $\left(103,000 \mathrm{~m}^{3}\right)$

\begin{tabular}{|c|c|c|c|c|c|c|c|c|}
\hline $\begin{array}{c}\text { Year } \\
(1)\end{array}$ & $\begin{array}{l}\text { Maximum } \\
\text { Irrigation } \\
\text { Depth } \\
(\mathrm{cm}) \\
(2)\end{array}$ & $\begin{array}{l}\beta \\
(3)\end{array}$ & $\begin{array}{c}\text { Value a of } b \\
(\mathrm{~kg} / \mathrm{ha}-\mathrm{cm}) \\
(4)\end{array}$ & \begin{tabular}{|} 
Optimal La \\
Depth Wh \\
Costs \\
Moderate \\
(cm) \\
$(5)$
\end{tabular} & $\begin{array}{l}\text { and Limiting } \\
\text { en Water } \\
\text { Are: } \\
\text { Expensive }{ }^{\text {b }} \\
\quad(\mathrm{cm}) \\
\quad(6)\end{array}$ & $\begin{array}{c}\text { L } \\
\text { Irrigation } \\
\text { Depth } \\
\text { (cm) } \\
\text { (7) }\end{array}$ & $\begin{array}{c}\text { Optimal W } \\
\text { Limiting Sol } \\
\text { Irrigation } \\
\text { Area } \\
\text { (ha) } \\
\text { (8) }\end{array}$ & $\begin{array}{l}\text { ter } \\
\text { Dryland } \\
\text { Area } \\
\text { (ha) } \\
\text { (9) }\end{array}$ \\
\hline 1952 & 60.5 & 0.78 & 205 & 60.5 & 60.2 & 53.8 & 19.1 & 33.6 \\
\hline 1953 & 49.5 & 0.80 & 214 & 49.5 & 49.5 & 43.9 & 23.4 & 29.2 \\
\hline 1954 & 45.7 & 0.79 & 233 & 45.7 & 45.7 & 39.9 & 25.7 & 26.9 \\
\hline 1955 & 57.2 & 0.79 & 215 & 57.2 & 56.9 & 51.8 & 19.8 & 32.8 \\
\hline 1956 & 26.7 & 0.70 & 248 & 26.7 & 26.2 & 19.6 & 52.6 & 0.0 \\
\hline 1957 & 30.5 & 0.76 & 236 & 30.5 & 30.2 & 21.1 & 48.7 & 3.9 \\
\hline 1958 & 22.9 & 0.52 & 258 & 21.8 & 19.8 & 19.6 & 52.6 & 0.0 \\
\hline 1959 & 53.3 & 0.78 & 227 & 53.3 & 53.3 & 47.2 & 21.7 & 30.9 \\
\hline 1960 & 41.9 & 0.78 & 237 & 41.9 & 41.9 & 35.1 & 29.3 & 23.3 \\
\hline 1961 & 38.1 & 0.79 & 242 & 38.1 & 38.1 & 32.3 & 31.9 & 20.7 \\
\hline 1962 & 19.1 & 0.72 & 257 & 19.1 & 18.8 & $19.6^{c}$ & 52.6 & 0.0 \\
\hline 1963 & 49.5 & 0.74 & 230 & 49.5 & 49.3 & 41.4 & 24.9 & 27.7 \\
\hline 1964 & 61.0 & 0.75 & 206 & 61.0 & 60.5 & 51.6 & 20.0 & 32.7 \\
\hline 1965 & 30.5 & 0.69 & 218 & 30.5 & 29.7 & 19.6 & 52.6 & 0.0 \\
\hline 1966 & 22.9 & 0.73 & 256 & 22.9 & 22.6 & 19.6 & 52.6 & 0.0 \\
\hline 1967 & 38.1 & 0.69 & 228 & 38.1 & 37.3 & 27.4 & 37.4 & 15.2 \\
\hline 1968 & 45.7 & 0.88 & 212 & 45.7 & 45.7 & 44.7 & 23.0 & 29.7 \\
\hline 1969 & 41.9 & 0.74 & 218 & 41.9 & 41.7 & 31.5 & 32.6 & 20.1 \\
\hline 1970 & 49.5 & 0.77 & 232 & 49.5 & 49.3 & 42.4 & 24.3 & 28.3 \\
\hline 1971 & 45.7 & 0.78 & 224 & 45.7 & 45.7 & 39.1 & 26.4 & 26.3 \\
\hline 1972 & 30.5 & 0.75 & 242 & 30.5 & 30.2 & 20.3 & 50.4 & 2.3 \\
\hline 1973 & 41.4 & 0.60 & 241 & 40.6 & 38.6 & 25.4 & 40.6 & 12.0 \\
\hline 1974 & 53.3 & 0.77 & 216 & 53.3 & 53.1 & 46.2 & 22.2 & 30.4 \\
\hline 1975 & 49.5 & 0.76 & 217 & 49.5 & 49.3 & 41.4 & 24.9 & 27.8 \\
\hline 1976 & 45.2 & 0.75 & 234 & 45.2 & 45.0 & 37.1 & 27.7 & 25.0 \\
\hline 1977 & 30.5 & 0.72 & 255 & 30.5 & 30.2 & 19.6 & 52.6 & 0.0 \\
\hline 1978 & 49.5 & 0.81 & 225 & 49.5 & 49.5 & 45.5 & 22.7 & 30.0 \\
\hline Mean & 41.9 & 0.75 & 231 & 41.8 & 41.4 & 34.7 & 33.8 & 18.8 \\
\hline
\end{tabular}

$a^{a} b=k_{y} Y_{m} / E T_{m} . E T_{m}$ varied for each year. $k_{y}=1.5, Y_{m}=10,060 \mathrm{~kg} / \mathrm{ha}$.

$\mathrm{b} 2$ and $5 \$ /$ ha-cm were used for moderate and expensive irrigation water.

c 1030 ha-cm was not a water limiting condition in 1962.

1 ha- $\mathrm{cm}=100 \mathrm{~m}^{3}$

irrigated area each year was calculated and compared to the optimal net return that year. The mean and the range from the mean plus and minus one standard deviation were calculated for the 27 years of data (Figure 6). The results show that the average relative net return is nearly constant over a range of irrigated areas. The results also show that it is generally not optimal to irrigate the entire area or to limit the irrigated area to less than 20 ha.

The finding that net returns are similar for a wide range of irrigated areas significantly reduces the consequences of following an incorrect strategy. Without prior weather information, one would select a strategy that is the same each year. The selected strategy should maximize average net returns over time, with an 
Table 6. Values of parameters used in optimization of center pivot operation for water limiting conditions

\begin{tabular}{|c|c|c|c|}
\hline (1) & $\begin{array}{l}\text { Description of variable } \\
\text { (2) }\end{array}$ & $\begin{array}{l}\text { Value } \\
\text { (3) }\end{array}$ & $\begin{array}{l}\text { Units } \\
(4)\end{array}$ \\
\hline$\overline{A_{t}}$ & Total irrigatable area & 52.6 & ha \\
\hline$C_{s}^{i}$ & Annual start-up cost of irrigation & 1,800 & $\$$ \\
\hline$C_{i}$ & Cost of irrigation water & 2.0 & \$/ha-cm \\
\hline$C_{1}$ & Annual production cost of irrigated corn & 284 & $\$ /$ ha \\
\hline$C_{d}$ & Annual production cost of dryland grain sorghum & 94 & $\$ /$ ha \\
\hline$D_{y}$ & $\begin{array}{l}\text { Yield of dryland sorghum - average } \\
\quad \text { (computed each year from dryland ET) }\end{array}$ & 3,520 & $\mathrm{~kg} / \mathrm{ha}$ \\
\hline$V_{d}$ & Net value of dryland grain sorghum & 0.11 & $\$ / \mathrm{kg}$ \\
\hline$V_{i}$ & Net value of irrigated corn & 0.12 & $\$ / \mathrm{kg}$ \\
\hline$W_{s}$ & Available water supply: water limiting conditions & 1,030 & ha-cm \\
\hline$Y_{d}$ & $\begin{array}{l}\text { Dryland corn yield - average } \\
\text { (computer each year from dryland ET) }\end{array}$ & 2,890 & $\mathrm{~kg} / \mathrm{ha}$ \\
\hline$Y_{m}$ & Maximum corn yield & 10,060 & $\mathrm{~kg} / \mathrm{ha}$ \\
\hline
\end{tabular}

1 ha-cm $=100 \mathrm{~m}^{3}$

acceptable variance that is consistent with the procedure's risk preference. The results depicted in Figure 6 show that both the highest mean net returns and the least variance are achieved by irrigating 28 to 32 ha. For this strategy, the mean net return averaged about $93 \%$ of what is possible given perfect prior information about the optimal strategy. Of greater significance for irrigation management, however, is the finding that a strategy of 25 to 40 ha would produce similar net returns most of the time.

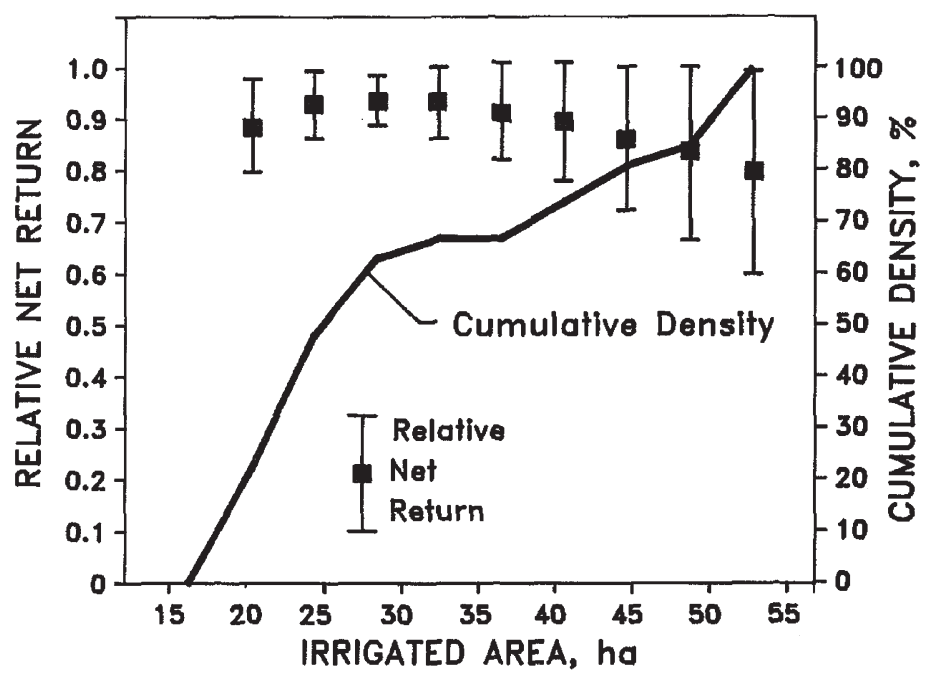

Figure 6. Cumulative density function for optimal irrigated area of corn and net return for specific irrigated areas relative to maximum net return for that year; range of relative net returns shown is mean \pm one standard deviation calculated from 27 years of data. 
Table 7. Ratio of optimal deficit irrigation depth relative to increase in ET when irrigating for maximum yield ${ }^{\text {a }}$

\begin{tabular}{ccccc}
\hline \multicolumn{5}{l}{ Value of $f$ parameter } \\
$\beta$ & 0.2 & 0.4 & 0.6 & 0.8 \\
$(1)$ & $(2)$ & $(3)$ & $(4)$ & $(5)$ \\
\hline 0.3 & 2.20 & 1.73 & 1.30 & 0.87 \\
0.5 & 1.78 & 1.56 & 1.26 & 0.90 \\
0.7 & 1.41 & 1.36 & 1.21 & 0.96 \\
0.9 & 1.11 & 1.11 & 1.11 & 1.06 \\
\hline
\end{tabular}

a Values are for $I^{\mathrm{O}} /\left(E T_{m}-E T_{d}\right)=I_{r}^{\mathrm{O}} / \beta$

${ }^{\mathrm{b}} f=\left[\left(V_{i} Y_{m}-C_{1}\right)-\left(Y_{d} D_{y}-C_{d}\right)\right] /\left[V_{i}\left(Y_{m}-Y_{d}\right)\right]$ (see text for definition of variables).

\section{Generalized Management Criteria}

The aforementioned examples can be used to formulate general management criteria. For land limiting situations, the optimal irrigation depth will be near the amount required to produce the maximum yield which is consistent with what others have shown. As the cost of irrigation water increases, the optimal irrigation depth decreases, but the cost of water must be quite high to reduce the irrigation depth substantially below that required for maximum yield. If irrigation is feasible, management for adequate water supplies generally reduces to scheduling irrigations to meet crop water requirements.

It is more difficult to manage a water supply that is inadequate than to produce the maximum yield on the irrigable area. For deficit irrigation, there is a trade-off between the area irrigated and the depth of water applied. Maximum irrigation requirements, crop values and production costs, and crop yields dramatically affect the optimal irrigation depth. The optimal irrigation depth relative to that required for maximum yield decreases as the efficiency of irrigation decreases. Even though the optimal relative depth decreases, the actual depth may be nearly the same as for more efficient systems since the gross irrigation requirement is larger for inefficient systems. Barrett and Skogerboe (1980) concluded that, because of this compensation, there is a narrow range of optimal irrigation depths regardless of the efficiency of the irrigation system. Yet others generally recommend spreading the available water over the entire irrigable area (Stewart and Hagan 1973).

These conclusions were tested using the generalized production function. The optimal irrigation depth was divided by the increase in ET above dryland conditions when irrigating for maximum yield $\left(E T_{m}-E T_{d}\right)$. The increase in $E T$ for maximum yield is independent of the efficiency of irrigation and normalizes the irrigation requirement. If the same actual depth should be applied for varying efficiencies, the ratio of the optimal depth to the ET increase should be constant for different efficiencies. Results show that the conclusion by Barrett and Skogerboe (1980) is nearly true for high values of the $f$ parameter but not for small values of $f$ (Table 7). Thus, there are situations where the water should be spread over the total irrigable area and others where a small area should be irrigated. The net return resulting from deficit irrigation appears to be insensitive to changes in the 
irrigated area over a wide range. However, the range can vary depending upon the costs, prices, and yield and water availability.

\section{Summary}

A method that uses physically based rather than empirical coefficients was developed to evaluate irrigation management strategies for a single season. The net return formulation allows for inclusion of different dryland and irrigated crops, which significantly affects irrigation management. The cost for the initial start-up of an irrigation systems was also included. Examples were developed to illustrate the use of the method to economically evaluate irrigation decisions. The methodology allows more extensive analysis of irrigation management problems than possible using a specific yield-irrigation relationship.

Generally, crops should be irrigated for nearly maximum yield when the water supply is unlimited, unless water costs are very high compared to the crop value. However, when water is limited, the appropriate management strategy is a continuum ranging from irrigating a small area for maximum yield to spreading a limited water supply uniformly over the irrigable area. The value of crop prices, costs, efficiency of irrigation, the amount of water available, and the crop response to irrigation determine the optimal practice. For water limiting conditions, about the same net return will be produced for a wide range of irrigated areas. This net return plateau reduces the consequences of selecting a suboptimal irrigated area.

\section{Acknowledgments}

The writers wish to thank the United States Geological Survey, United States Department of Interior, under Grant No. 14-08-0001-0-1141, for partial funding of this research. The study was also sponsored by the Nebraska Agricultural Research Division. This manuscript is Journal Series No. 8448 of the Nebraska Agricultural Research Division.

\section{References}

Barrett, J. W. H., and Skogerboe, G. V. (1980). “Crop production functions and the allocation and use of irrigation water." Agric. Water Mgmt. 3(1), 53-64.

Doorenbos, J., and Kassam, A. H. (1979). "Yield response to water." Irrig. and Drain. Paper No. 33, Food and Agric. Org. of United Nations, Rome, Italy.

Doorenbos, J., and Pruitt, W. O. (1977). "Guidelines for predicting crop water requirements." Irrig. and Drain. Paper No. 24, Food and Agric. Org. of United Nations, Rome, Italy.

Martin, D. L., Watts, D. G., and Gilley, J. R. (1984). "Model and production func tion for irrigation management." J. Irrig. and Drain., ASCE, 110(2), 149-164.

Maurer, R. E. (1981). "Effect of timing and amount of irrigation and drought stress conditioning in corn," thesis presented to the University of Nebraska-Lincoln, in partial fulfillment of the requirements for the degree of Doctor of Philosophy.

Skogerboe, G. V., Barrett, J. W., Treat, B. J., and McWhorter, D. B. (1979). “Potential effects of irrigation practices on crop yields in Grand Valley." Proj. Rep. EPA-600/2-79-149, U.S. Envir. Protection Agency, Office of Res. and Development, Ada, Okla.

Stewart, J. I., and Hagan, R. M. (1973). "Functions to predict effects of crop water deficits." J. Irrig. and Drain., ASCE, 99(4), 421-439. 
Stewart, J. I., et al. (1975). "Irrigating corn and grain sorghum with a deficit water supply." Trans. Am. Soc. of Agric. Engrs. 18(2), 270-280.

Stewart, J. I., et al. (1977). “Optimizing crop production through control of water and salinity levels in soils." Utah Water Res. Lab., FRWG 151-1, Utah State Univ., Logan, Utah.

Yaron, D., and Bresler, E. (1983). "Economic analysis of on-farm irrigation using response functions of crops." Advances in irrigation, D. Hillel, ed. Vol. 2, Academic Press, New York, N.Y., 224-256.

\section{Notation}

The following symbols are used in this paper:

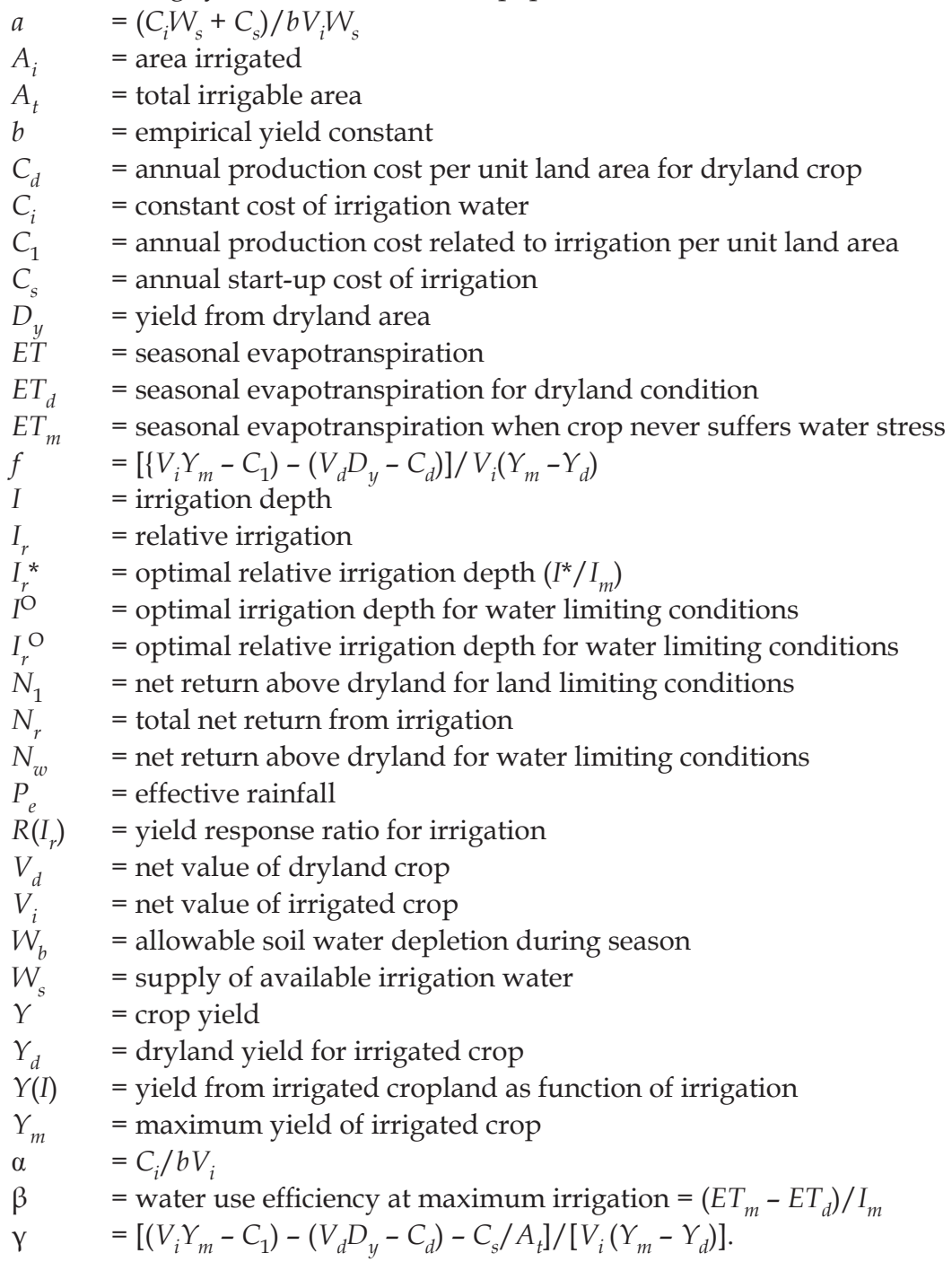

